\title{
Status and distribution of the White-bellied Shortwing Brachypteryx major in the Western Ghats of Karnataka and Goa, India
}

\author{
V. V. ROBIN, R. SUKUMAR and J.-M. THIOLLAY
}

\begin{abstract}
Summary
The White-bellied Shortwing is a Globally Threatened, endemic bird found in the Western Ghats of southern India. Given the few recent records of the species from its range, its population is thought to have dwindled with increasing habitat fragmentation and disturbance. A previous survey covered the states of Kerala and Tamil Nadu while this survey covers the states of Karnataka and Goa; thus together the two surveys cover the species' entire prospective range. The survey resulted in 11 sightings of White-bellied Shortwing in the unique shola forests. Encounter rates in Karnataka were much lower than in Kerala and Tamil Nadu, while no shortwings were sighted in Goa. Effects of sampling effort and detectability were examined as probable causes of the low encounter rates and one site was re-sampled. Conservation problems are highlighted and suggestions are made.
\end{abstract}

\section{Introduction}

The White-bellied Shortwing Brachypteryx major is one of the threatened species (Vulnerable BI+2a,b,c,d,e; BirdLife International 2001) of the Western Ghats, a global biodiversity hotspot. Once reported to be fairly common (Ali and Ripley 1987), there have been only a few recent records of White-bellied Shortwing, the most likely causes of its decline being the loss of its montane evergreen habitat and continuing habitat fragmentation and degradation (Birdlife International 2001). The White-bellied Shortwing occurs as two subspecies, B. m. major and B. m. albiventris, separated by a geographical gap in the Western Ghats (Palaghat gap), with the former and latter distributed to the north and south of the gap respectively.

During a previous study (Robin and Sukumar 2002), the forests of Kerala and Tamil Nadu were visited in the first phase of an attempt to estimate the current status of the species across the whole Western Ghats. The study recorded 214 sightings and demonstrated that the shortwing preferred shola forests above $1,500 \mathrm{~m}$ but was also present at lower abundances in shola forest between 1,000 and $1,500 \mathrm{~m}$. The current survey was of the subspecies B. m. major in Karnataka and Goa part of the Western Ghats, to the north of the Palaghat gap. There are only a few old records (most over 6o years ago) from Karnataka of this bird and there were no recent records until this survey was implemented.

\section{Methods}

The major part of the fieldwork was conducted from 25 January to 30 March 2002. This period of sampling was chosen to make the results of this study comparable with 
the previous one and to counter any difference in detection probability due to seasonal changes. The second phase of the survey was conducted from 20 April to 10 May 2004.

\section{Survey area selection}

The areas to be surveyed were chosen based on the background information collected during the previous survey (Robin and Sukumar 2002). We primarily targeted all areas that could be possible White-bellied Shortwing habitats: shola forests (described in the following section). As some areas in North Karnataka and Goa do not have this habitat historically and these areas also do not have forests in the elevation range preferred by the shortwing (above 1,000 m), we surveyed the highest regions available in these areas to double-check the northernmost limits of the species. We incorporated old records and birdwatchers' records while deciding on the areas to be surveyed. We did not rely on information from tribesmen or other local people as most could not identify the species with confidence.

\section{Data collection}

Trails inside the forest were walked in the mornings (o7hoo to 12hoo) and afternoon (I4hoo 18hoo) while looking and listening for the White-bellied Shortwing. The habitats sampled were categorized into tropical wet evergreen forest following Champion and Seth (1968) and montane temperate forest which is locally known as shola forest (for a description of the latter see Meher-Homji 1984). Altitude (using an altimeter, Thommen Classic) and habitat type were recorded every $0.5 \mathrm{~km}$ (distance measured with a pedometer). White-bellied Shortwings were detected by direct sighting or by calls. Due to previous experience with the species, its calls could be identified with confidence. Once the species was detected, the distance from the starting point was recorded together with the altitude and the GPS location (whenever possible). While recording the number of individuals at a place using calls, only the number of individuals heard simultaneously were recorded so as to avoid duplication.

Results of the previous survey in Kerala and Tamil Nadu indicated that shortwings were found close to streams (Robin and Sukumar 2002). To increase the probability of detecting shortwings in this present survey, a minimum of 5 minutes was spent listening for the call of the bird at all streams encountered during the sampling walks.

In the second phase of sampling in Bababudan Hills, we spent 10 minutes every 200 $\mathrm{m}$ in an attempt to detect shortwings by their vocalizations. We walked the same path twice to confirm the presence or absence of the shortwing.

\section{Data analysis}

The sampling effort and the sightings were classified into two elevation categories: o$1,000 \mathrm{~m}$ and $>_{1,000} \mathrm{~m}$. The encounter rate of shortwings was calculated as the number of sightings divided by the distance sampled in kilometres.

\section{Preparation of map}

To map the distribution of the species, maps were procured from www.iscgm.org and the elevation map was used to generate contours at 1,000 $\mathrm{m}$ and 1,500 m. Sampling 
White-bellied Shortwing Brachypteryx major in the Western Ghats of Karnataka and Goa, India

points were plotted on this map with the state boundaries to produce the final map using ArcView v.3.oa.

\section{Results and discussion}

A total of $116.5 \mathrm{~km}$ was sampled in the forests of Karnataka and Goa between 27 January and 27 March 2002 and resulted in 11 sightings (Figure 1). An attempt was made to cover at least 8-10 km of forest at every site. There were no records from Goa; all 11 sightings were from one site: Kemmangundi in the Bababudan Hills. The sampling locations and effort are shown in the Appendix.

Vegetation types and elevation range

Only two vegetation types were surveyed: evergreen forests and shola forests. There were 11 sightings of the shortwing from the $65 \mathrm{~km}$ of shola forests sampled (encounter

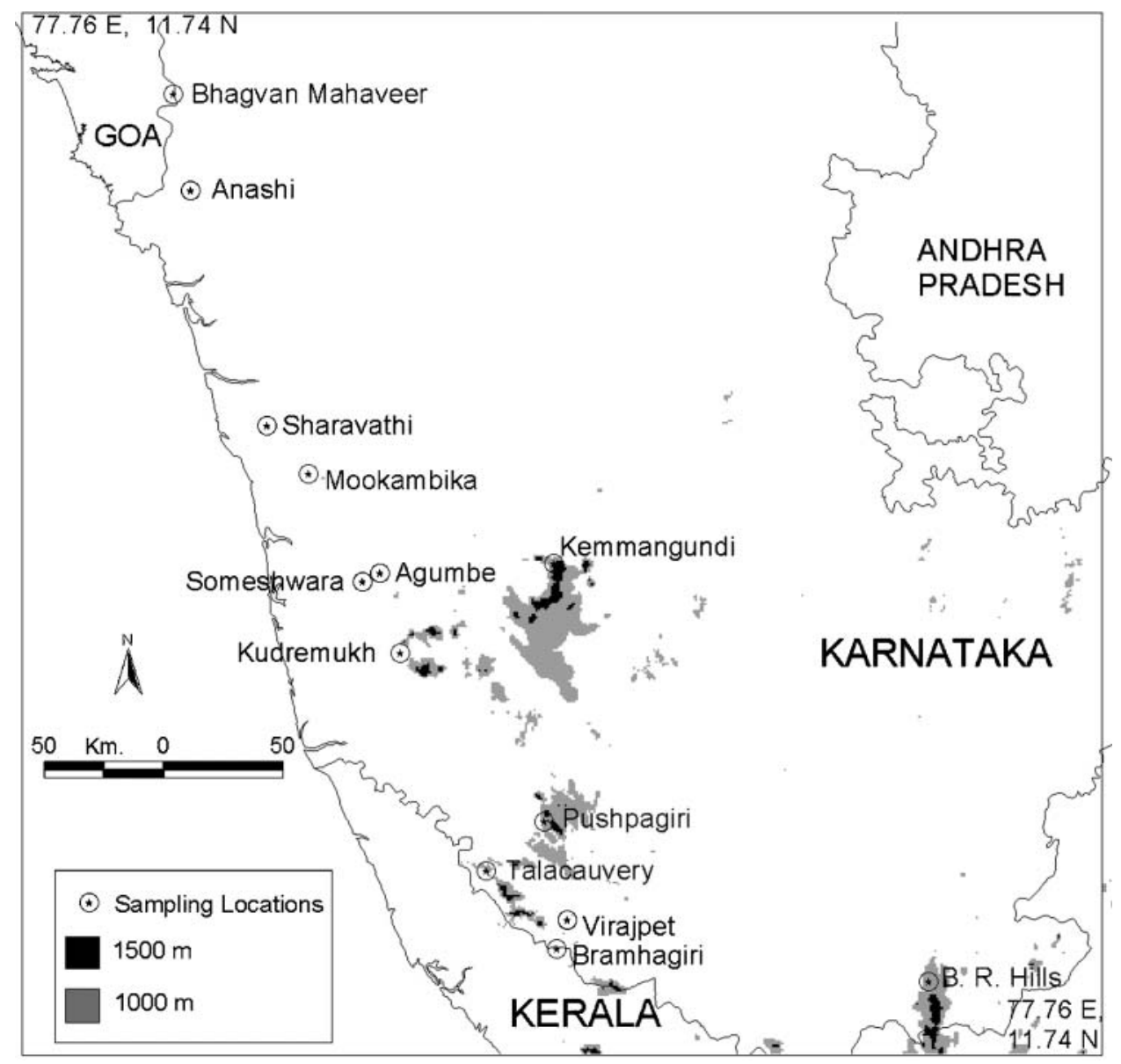

Figure 1. Sampling locations in different altitudinal ranges of Karnataka and Goa for the White-bellied Shortwing in 2002. 
rate $=0.17$ White-bellied Shortwings $/ \mathrm{km}$ ) whereas no sightings resulted from 51.5 $\mathrm{km}$ of sampling in the evergreen forests. Shortwings were not sighted in many small shola patches on isolated mountain tops where the lower slopes were drier forests and where there were no sholas nearby.

Eight of the 13 sites sampled were above $1,000 \mathrm{~m}$ elevation and the highest forest sampled was $1,700 \mathrm{~m}$ at Biligiri Rangaswamy Temple (BRT) Wildlife Sanctuary. The shortwings were found only in forests above $1,000 \mathrm{~m}$, where $73 \mathrm{~km}$ of sampling resulted in 11 sightings. Though $37.3 \%(43.5 \mathrm{~km})$ of the sampling was in forests below 1,000 $\mathrm{m}$ it did not result in any sightings. Although all the sightings were from Bababudan Hills at an average sampled elevation of $1,470 \mathrm{~m}$, there were other sites that were sampled at much higher elevations (Appendix) but resulted in no sightings. In Kerala and Tamil Nadu the number of shortwing sightings was found to increase with elevation (Robin and Sukumar 2002); however, such a trend was not seen in Karnataka.

The previous study in Kerala and Tamil Nadu (Robin and Sukumar 2002) concluded that the prime White-bellied Shortwing areas, shola forests above 1,500 m, had a higher encounter rate $(2.08$ shortwings $/ \mathrm{km})$ than 'secondary' areas, sholas between 1,000 and $1,500 \mathrm{~m}(0.38$ shortwings $/ \mathrm{km}$ ). However, the encounter rate from the forests surveyed in Karnataka is only around half of that of the secondary areas in Kerala and Tamil Nadu. This indicates that the abundance of the White-bellied Shortwing is lower in Karnataka than in the other two states. The encounter rate from the only site that resulted in sightings, Bababudan Hills, when examined alone, was also more similar to the secondary shortwing areas of Kerala and Tamil Nadu. There were also no sightings of shortwings from forests adjoining human habitation, contrary to the results of the previous study.

We examined the difference in sampling effort as one of the reasons for lower encounter rates; however, there was no significant difference in the mean sampling effort at sites above $1,000 \mathrm{~m}$ between the two studies (Mann-Whitney $U$-test, $Z=$ $0.482, P=0.67, \mathrm{n}=17,18$, ). Since we ruled out disproportionate sampling effort as a factor affecting the encounter rates, we propose that a difference in detectability could have resulted in low encounter rates.

Of all White-bellied Shortwing detections, $63 \%$ were from songs, and singing is a seasonal behaviour usually exhibited in the breeding season. The survey in Karnataka was conducted at exactly the same time and by the same observer as the survey in Kerala and Tamil Nadu to avoid confounding the results with seasonality or observer bias. However, 2002 turned out to be a drought year in Karnataka, with 30-45\% less rainfall than normal (Down to Earth, 15 January 2003). If the birds were breeding later than usual, it is likely that we did not hear them singing at the time of sampling. We therefore proposed a second bout of sampling in Bababudan Hills in 2004 to check for any variation in encounter rates. In the second bout of sampling we covered $9 \mathrm{~km}$ twice but obtained only two sightings of shortwings. This resulted in a lower encounter rate (o.11) than the previous survey. We also re-sampled one site in Ooty (Tamil Nadu), a site previously surveyed and classified as a prime White-bellied Shortwing area. Resampling with the same methods resulted in 15 sightings from $8 \mathrm{~km}$ of sampling (encounter rate of 1.9 shortwings $/ \mathrm{km}$ ). We concluded from this that sampling effort and detectability are not the causes of the low encounter rates in Karnataka, and that the shola forests in Karnataka do have inherently low densities of the species. Other methods of detecting the shortwings (mist-netting) and more intensive sampling could be used in further studies. Only a detailed inquiry into the biology of the shortwing 
involving the study of foraging, breeding and population dynamics would throw some light into the causes of the low abundance of the species in these areas.

Though no sightings were obtained from Coorg Reserve forests, Brahmagiri Wildlife Sanctuary, Kudremukh National Park and BRT Wildlife Sanctuary, these areas are likely to have White-bellied Shortwing populations though in low densities. The previous records (Ali and Ripley 1987, BirdLife International 2001) do suggest that these birds occur in Brahmagiris and there has been a recent record of shortwing presence from this area (Thejaswi 2004). Thejaswi (2004) reported sightings from Kodachadri (Mookambika Wildlife Sanctuary) and Kudremukh National Park, though there are no historical records from these areas. However, results of the two studies cannot be compared as Thejaswi (2004) does not indicate the sampling effort or the number of sightings.

\section{Conservation significance}

The evidence of the White-bellied Shortwing still being found in Bababudan Hills more than 60 years after previous records is indicative that the species has survived in spite of intense human pressure. The population in Bababudan Hills is particularly important for conservation as the forests in these areas are under the category with least protection (reserve forests). The Western Ghats has lost $25.6 \%$ of its forest cover in the last two decades (Jha et al. 2000) and there has been a loss of $50 \%$ of shola forests since 1850 (Sukumar et al. 1995). This problem is even more relevant as the Bababudan Hills continue to face habitat loss and disturbance due to human pressures from large tracts of coffee plantations created in the last century and active, large-scale mining of iron ore. Kudremukh National Park, where iron ore mining has been prevalent, has recently been ordered by the Supreme Court of India to be shut, and such strong conservation actions are required to save the remaining populations of White-bellied Shortwings and their habitat. The first step towards this would be raising the level of protection of the forests that support shortwings. Shola forests in other areas in Karnataka are also being threatened, particularly Kodachadri and Coorg. This action might be important for Karnataka as, unlike Tamil Nadu or Kerala, there are not many areas with shola forests in this state.

Appendix. Classification of sampling effort and sightings at sampled locations in Karnataka and Goa in 2002.

\begin{tabular}{|c|c|c|c|c|c|}
\hline \multirow[t]{3}{*}{ Sampling locations and sampled elevation range (m) } & & \multicolumn{4}{|c|}{ Habitat type } \\
\hline & & \multicolumn{2}{|c|}{ Shola forest } & \multicolumn{2}{|c|}{ Evergreen forest } \\
\hline & & $\begin{array}{l}\text { Below } \\
\text { 1,ooo m }\end{array}$ & $\begin{array}{l}\text { Above } \\
1, \text { ooo m }\end{array}$ & $\begin{array}{l}\text { Below } \\
1, \text { ooo m }\end{array}$ & $\begin{array}{l}\text { Above } \\
1, \text { ooo m }\end{array}$ \\
\hline Agumbe Reserve Forest (610-710) & $\mathrm{km}$ & & & 6 & \\
\hline & no. & & & o & \\
\hline Anashi National Park (550-580) & $\mathrm{km}$ & & & 5 & \\
\hline Bhagwan Mahavir Wildlife Sanctuary (350) & $\begin{array}{l}\mathrm{km} \\
\text { no. }\end{array}$ & & & $\begin{array}{l}7 \cdot 5 \\
0\end{array}$ & \\
\hline Bramhagiri Wildlife Sanctuary $(930-1,480)$ & $\mathrm{km}$ & & 8.5 & 3 & 1 \\
\hline & no. & & o & O & o \\
\hline
\end{tabular}




\begin{tabular}{|c|c|c|c|c|c|}
\hline \multirow[t]{3}{*}{ Sampling locations and sampled elevation range $(\mathrm{m})$} & & \multicolumn{4}{|c|}{ Habitat type } \\
\hline & & \multicolumn{2}{|c|}{ Shola forest } & \multicolumn{2}{|c|}{ Evergreen forest } \\
\hline & & $\begin{array}{l}\text { Below } \\
1, \text { ooo m }\end{array}$ & $\begin{array}{l}\text { Above } \\
1, \text { ooo } \mathrm{m}\end{array}$ & $\begin{array}{l}\text { Below } \\
1, \text { ooo m }\end{array}$ & $\begin{array}{l}\text { Above } \\
1, \text { ooo } \mathrm{m}\end{array}$ \\
\hline Billigiri Rangasway Temple Sanctuary $(1,550-1,700)$ & $\begin{array}{l}\mathrm{km} \\
\mathrm{no}\end{array}$ & & $\begin{array}{l}9 \\
0\end{array}$ & & \\
\hline Kemangundi Reserve Forest $(1,440-1,530)$ & $\begin{array}{l}\mathrm{km} \\
\mathrm{no}\end{array}$ & . & $\begin{array}{l}17 \\
11\end{array}$ & . & . \\
\hline Kollur Wildlife Sanctuary $(620-1,150)$ & $\begin{array}{l}\mathrm{km} \\
\mathrm{no}\end{array}$ & $\begin{array}{l}0.5 \\
0\end{array}$ & $\begin{array}{l}2.5 \\
0\end{array}$ & $\begin{array}{l}4 \\
0\end{array}$ & \\
\hline Kudremukh National Park (1,00o-1,580) & $\begin{array}{l}\mathrm{km} \\
\text { no. }\end{array}$ & & $\begin{array}{l}9 \cdot 5 \\
0\end{array}$ & $\begin{array}{l}1.5 \\
0\end{array}$ & $\begin{array}{l}4 \cdot 5 \\
0\end{array}$ \\
\hline Pushpagiri Wildlife Sanctuary $(1,000-1,440)$ & $\begin{array}{l}\mathrm{km} \\
\mathrm{no}\end{array}$ & & $\begin{array}{l}4 \cdot 5 \\
0\end{array}$ & $\begin{array}{l}0.5 \\
0\end{array}$ & $\begin{array}{l}3 \\
0\end{array}$ \\
\hline Sharavathi Wildlife Sanctuary (210-46o) & $\begin{array}{l}\mathrm{km} \\
\mathrm{no}\end{array}$ & & & $\begin{array}{l}7 \\
0\end{array}$ & \\
\hline Someshawara Wildlife Sanctuary (180-190) & $\begin{array}{l}\mathrm{km} \\
\mathrm{no}\end{array}$ & & & $\begin{array}{l}8.5 \\
0\end{array}$ & \\
\hline Virajpet Reserve Forest (1,250-1,450) & $\begin{array}{l}\mathrm{km} \\
\mathrm{no}\end{array}$ & & $\begin{array}{l}7 \\
0\end{array}$ & & \\
\hline Talakaveri Wildlife Sanctuary $(1,190-1,375)$ & $\begin{array}{l}\mathrm{km} \\
\mathrm{no}\end{array}$ & & $\begin{array}{l}6.5 \\
0\end{array}$ & & \\
\hline
\end{tabular}

$\mathrm{km}$, length of transect in kilometres; no., number of sightings.

\section{Acknowledgements}

This project was supported by Bombay Natural History Society (BNHS), Asian Nature Conservation Fund and the Nityata Foundation. V. V. R. would like to thank Mr J.C. Daniel, Dr Asad Rahmani, Mr M.O. Sriram, Mr Surendra Varma, Mr Gopakumar Menon and Dr Jamadagni for their cooperation in this project. We would like to thank the Forest Departments of Karnataka and Goa for their complete support and wholehearted cooperation during the field study. We also thank Dr N.V. Joshi, Dr Arun Venkataraman, Ms Nandini Rajamani, Mr Julien Cornut, Mr N. Sambakumar, Dr Narasimhan in Virajpet, Mr Bhat from Sirsi, Mr Nilesh Kulkarni, in Goa, Mr Bomma and Mr Kumar for field assistance.

\section{References}

Ali, S. and Ripley, S. D. (1987) Compact handbook of the birds of India and Pakistan. Bombay: Oxford University Press.

BirdLife International (2001) Threatened birds of Asia: the BirdLife International Red Data Book. Cambridge, U.K: BirdLife International.

Champion, H. G. and Seth, S. K. (1968) A revised survey of the forest types of India. New Delhi: Government of India Press.

Jha, C. S., Dutt, C. B. S. and Bawa, K. S. (200o) Deforestation and land use changes in the Western Ghats, India. Curr. Sci. 80: 378-388.

Meher-Homji, V. M. (1984) Udhagamandalam (Ootacamund): a biogeographic perspective. Indian Geog. J. 59: 205-213. 
White-bellied Shortwing Brachypteryx major in the Western Ghats of Karnataka and Goa, India

Robin, V. V. and Sukumar, R. (2002) Status and habitat utilisation of the threatened Whitebellied Shortwing Brachypteryx major in the Western Ghats (Kerala and Tamil Nadu), India. Bird Conserv. Int. 12: 335-351.

Shanker, K. and Sukumar, R. (1999) Synchrony in small mammal populations of montane forest patches in southern India. J. Anim. Ecol. 68: 50-59.

Thejaswi, S. (2004) Kemmangundi revisited: notes on birds observed at the Bababudan hills, Karnataka, India. J. Bombay Nat. Hist. Soc. 101: 235-243.

Sukumar, R., Suresh, S. H. and Ramesh, R. (1995) Climate change and its impact on tropical montane ecosystems in southern India. J. Biogeog. 22: 533-536.

V. V. ROBIN ${ }^{1 *}$, R. SUKUMAR ${ }^{1}$

Research Associate, National Institute of Advanced Studies, Indian Institute of Science campus, Bangalore 560012, India.

J.-M. THIOLLAY

CERSP, CRBPO, 55 rue de Buffon, 75005 Paris, France.

${ }^{1}$ Centre for Ecological Sciences, Indian Institute of Science, Bangalore 560012, India

*Author for correspondence; E-mail: robinvvijayan@yahoo.com

Received 29 June 2005; Accepted 1o February 2006 